coronary arteries. The remainder of the carcass, devoid of aorta and liver, was dried, and nitrogen and oxtractable lipid determined ${ }^{3}$.

All the results are given in Table 1. The protein intake of the restricted group was approximately 60 por cent of that of the normal group. This was reflected in a significantly lower body-weight at the end of the 20-month experimental period. There was no difference botween the two groups, however, in the percentages of body nitrogen and extractable lipid.

As in our previous studies ${ }^{1,2}$, there was a significantly higher plasma cholesterol concentration in the group of cocks on the restricted protein intake. This difference was not reflocted in differences in liver cholesterol values. There was no difference in aortic atheroselerosis as judged by either macroscopic or histological scoring. The coronary arteries, however, showed markodly greator severity of atherosclerosis for the cocks on the normal protein intake in comparison with those on the restricted intake. Thoso observations lend further emphasis ${ }^{4,5}$ to the poor correlation between cholosterol values and the incidence and severity of atherosclerosis.

In contrast to the present observations, Stamler et al. ${ }^{\circ}$ obsorved an increased incidenco of lesions with low-protein diets; their data indicato, however, that the protein-lovel considored 'low' was adequate for normal growth as judged by a comparison of the final weights of the 'low' and high-protein groups.

In the fowl, spontaneous coronary athoroselerotic lesions do not develop in parallel with, and are generally less severe than, those of the abdominal aorta?. It may $b e$ that in the fowl, as in man, whore the coronary arteries and the aorta are often affected to different degrees by atherosclorosis, these two sites react differontly to atherogenic stimuli. This may bo why loss-sevore coronary Iesions were observed in birds after a restricted protein intake while no difference was seen in tho aortic lesions.

This work was supportod in part by grants from the U.S. Public Hoalth Service and the Sussex and Monmouth County Hoart Associations.

Department of Animal Sciences, Hans Fisher W. G. SILLER P. Griminger

Rutgers-The State University,

New Brunswick, New Jersey, and

Poultry Research Centre, Edinburgh.

${ }^{1}$ Fisher, H., Feigenbaum, A. S., Leveille, G. A., Weiss, H. S., and Griminger P., J. Nutr., 68, 163 (1959).

${ }^{2}$ Feigenbaum, A. S., Fisher, H., Leveille, G. A., Weiss, H. S., and Griminger, P., J. Amer. Oil. Chem. Soc., 38, 93 (1961).

${ }^{3}$ Fisher, H., and Griminger, P., J. Nutr., 80, 350 (1963).

${ }^{4}$ Fisher, H., Griminger, P., Wciss, H. S., and Siller, W. G., Science, 146, 1063 (1964).

${ }^{5}$ Fisher, $\amalg$. , and Kaunitz, H., Proc. Soc. Exp. Biol. and Med., 116, 278 (1964).

- Stamler, S., Pick, R., and Katz, L. N., Circ. Res., 6, 447 (1958).

${ }^{7}$ Siller, W. G., in Comparative Atherosclerosis : Spontaneous and Experimental (Hoeber, New York, in the press).

\section{Premature Delivery and Survival in Lambs}

BeFore 105-110 days gestational age (term is about 147 days) it is impossible to obtain independent survival of lambs delivered by Caesarean section, even on ventilation with 100 per cent oxygen ${ }^{1}$. This estimate of the ultimate limit of viability in sheep agrees well with the histological changes which begin in the lungs at about 90 days gestation $^{2}$. The lamb is very mature at birth, so there was every reason to suppose that most lambs delivered prematurely would survive. However, 23 Clun-Hampshire lambs survived after being delivered (by Caesarean section under local or epidural anaesthesia) at 142 days gestation or more, whereas 4 of 23 that were delivered at 138-141 days gestation did not survive. The weights of these 4 lambs were $3 \cdot 3-4 \cdot 2 \mathrm{~kg}$ and they all appeared well developed. But they failed to maintain spontaneous breathing for more than a few minutes after the umbilical cord was tied, in spite of prolonged efforts at resuscitation by positive pressure ventilation with oxygen.

This large mortality rate was surprising, because 138 days represents 94 per cent of normal term in sheep, and one expects that all infants should establish normal respiration on premature delivery after only 90 per cent of term in man or rhesus monkeys, when instances of gross anomalies and disease are excluded. However, the numbers involved were small and therefore enquiries have been made into the losses of newborn lambs in flocks where accurate records of tupping dates were available.

The causes of perinatal wastage in lambs under field conditions are various. Hence, in examining that portion of the perinatal mortality rate which may fairly be attributed to temporal prematurity, certain criteria must be met. The data presented below refor only to sheep in supervised recorded flocks with individual mating dates and a high standard of antenatal care under competent daily inspection; the flocks have been free for at least 5 years from any clinical evidence of contagious illness known to affect pregnancy; the pregnancies were uncomplicated and lasted more than 90 per cent of the normal gestation length (132-135 days), and with normal parturition yielding lambs free of physical defects and of minimal viable birth weights $(2.75 \mathrm{~kg}$ for males and $2.25 \mathrm{~kg}$ for females of the breeds concerned); they include cases only of recent stillbirth, death during parturition, and death in the first $24 \mathrm{~h}$ after birth.

Data meeting these criteria have beon assembled for 1,077 pregnancies during 1960-64 in four flocks of two pure breeds, breed $A$ being similar to the Clun-Hampshire and breed $B$ being somewhat smaller. The mean gestation length of breed $A$ is said to be 147 days and our figures endorse this estimate; that for breed $B$ is thought to be longer and may be 149-150 days, with which our limited data concur.

For proliminary study over some years we have accepted a variation of 5 per cent about the mean gestation length as the normal range, that is, 144-150 days in breed $A$ and 146-154 days in breed $B$. A lamb born after a gestation shorter than this is considered prematuro, a 2.5 per cent shortening being considered slight temporal prematurity (141-143 days for breed $A$ and 144-146 days for breed $B$ ) while a gestation only 95-90 per cent of the mean was considered as marked temporal prematurity in the larmbs.

Table 1. Effects of Premature Delivery on Survival in Sirefp

\begin{tabular}{|c|c|c|c|c|c|}
\hline \multirow[b]{2}{*}{ Delivered at term $+2.5 \%$} & \multicolumn{5}{|c|}{ Breed and flock } \\
\hline & $A 8$ & $A 20$ & $A 38$ & 'Iotal $A$ & $B 2$ \\
\hline Mean gestation age (days) & $147 \cdot 2$ & $147 \cdot 0$ & $147 \cdot 6$ & $147 \cdot 3$ & $149 \cdot 3$ \\
\hline Av. litter size & $1 \cdot 81$ & 1.87 & 1.87 & $1 \cdot 86$ & 1.51 \\
\hline No. litmbs & 261 & 1,131 & 339 & 1,721 & 226 \\
\hline Deaths & 27 & 107 & 33 & 167 & 26 \\
\hline$\%$ dead & $10 \cdot 3$ & $9 \cdot 5$ & $9 \cdot 7$ & $9 \cdot 7$ & 11.5 \\
\hline $\begin{array}{l}\text { Delivered at term less } 2 \cdot 5-5 \% \text { : } \\
\text { Ay Jitter size }\end{array}$ & 1.07 & 1.87 & & & \\
\hline $\begin{array}{l}\text { Av. Inter size } \\
\text { No. lambs }\end{array}$ & $10^{10}$ & 28 & 14 & 5200 & 2100 \\
\hline Deaths & 2 & 6 & 5 & 13 & 12 \\
\hline$\%$ dead & 20 & 21 & 36 & 25 & 57 \\
\hline $\begin{array}{l}\text { Delivered at term less } 5-10 \% \text { : } \\
\text { A verage litter size } \\
\text { No. lambs } \\
\text { Deaths }\end{array}$ & E & $\begin{array}{l}1 \cdot 8 \\
9 \\
8\end{array}$ & $\begin{array}{l}2 \\
2 \\
2 \\
2\end{array}$ & $\begin{array}{l}\mathbf{7 \cdot 8} \\
11 \\
10\end{array}$ & $\begin{array}{l}1 \cdot 5 \\
3 \\
2\end{array}$ \\
\hline
\end{tabular}

ssociation between survival at birth and maturity $(P<0.001)$

Table 1 shows that for similar average litter sizes, the perinatal mortality rises from about 10 per cent for fullterm lambs to 25 per cent or more for slightly premature lambs, and even higher for markedly premature lambs. Hence lambs of gestational age less than 95 per cent of the normal, that is, of 5 per cent prematurity, are not of normal viability. In this respect the lamb appears to differ from man, rhesus monkey and cattle. The mortality rate on delivery at term also compares very unfavourably with that in man.

G. S. DAwES

Nuffield Institute of Medical Research,

H. B. PARRY University of Oxford.

${ }^{2}$ Born, G. V. K., Dawes, G. S., and Mot1, J. C., J. I'hysiol., 130, 191 (1955). ${ }^{2}$ Fauré-liremiet, E., and Dragoiu, J., Arch. Anat. Mirr., 19, 411 (1923). 